\title{
Status of Wetlands Conservation in Bardia National Park
}

Tikaram Adhikari, Ramesh K. Thapa and Jhamak B. Karki ${ }^{1}$

\begin{abstract}
The study of manmade waterhole was carried from July 14, 2009 to July 22, 2009. The surface area and water depth was estimated. Most of the manmade waterholes lie in the Sal Forest of lowland plains and in the Lamkauli Phanta, where ground vegetation is low and wildlife visibility is high. The signs of fauna such as pellets/scat/hoof marks/footprints/feedings remains, scratch etc were recorded. The main objective of this study was to keep record of wildlife observed directly or recorded indirectly in the manmade waterhole, to determine its uses by fauna and, to estimate quantity of water in the manmade waterhole during hot summer seasons. These places are very close to human settlements around east-west highway. These areas are easily accessible so that even poacher can take advantage. Generally, waterhole sites are considered as high risk places for poaching. Therefore, it is necessary to develop a system to patrol and monitor regularly to protect wildlife.

यस मानव निर्मित वाटरहोल सम्बन्धिको अध्ययन सन् २००९ को जुलाई १४ देखि जुलाई २२ सम्म गरिएको थियो। जसमा सतही क्षेत्रफल र पानीको गहिराइको अनुमान गरिएको थियो। जनावरहरुका संकेत जस्तै दिशा, खुर, खुट्टाको छापहरु, खाँदै गर्दा बाँकी रहको आहारा आदिको रेकर्ड गरिएको थियो। यस अध्ययनको मुख्य उदेश्य मानव निर्मित वाटरहोलमा प्रत्यक्ष भेटिएका जनावरहरु र अप्रत्यक्ष रुपमा रेकर्ड गरिएका जनावरहरुको रेकर्ड राखी, जनावरहरुले वाटरहोलको रुपमा बारे पत्ता लगाउनु साथै गर्मी याममा वाटरहोलमा चाहिने पानीको मात्रा पत्ता लगाउनु हो। धैरै जसो मानव निर्मित वाटरहोलहरु सालको जंगलमा लामकौली फाँटमा रहेका छन्। जहाँ भूईंमा वनस्पतिहरु कम छन् र जनावरहरु सजिलैसँग देख्न सकिन्छ। यि ठाउँहरु वस्ती एवं पूर्व-पश्चिम राजमार्गको नजिक पर्दछन् र सजिलै आवतजावत गर्न सकिने भएकोले शिकारीहरुले शिकार को फाईदा पनि लिईरहेका छन्। सामान्यतया वाटरहोल रहेका ठाउँहरु शिकारको लागि खतरायुक्त क्षेत्रको रुपमा लिईन्छ। त्यस कारण वन्यजन्तुको संरक्षणक लागि नियमित रुपमा गस्ति एवं अनुगमन गर्ने प्रणालीको आवश्यकता देखिन्छ।
\end{abstract}

\section{Introduction}

Water is a vital energy of living beings. In Bardia National Park (BNP), two major rivers, Karnali and Babai, and their tributaries have created a wonderful prime habitat of wildlife. A number of rare and endangered species home in the flood plain. These rivers have created a number of ox-bow lakes which are being most prominent habitat of a number of rare and endangered species such as the greater one horned rhino (Rhinoceros unicornis), the royal bengal tiger (Panthera tigris), the asiatic wild elephant (Elaphus maximus), the ghairal (Gavialis gangeticus), marsh crocodile (Crocodylus palustris), Gangetic dolphin (Platanista gangetica), and water birds.

Geographically, the park consists of Siwalik hill, Bhabar, flood plain and the lowland plain. In spite of Karnali and Babai rivers, there are a number of streams flowing across the Siwalik

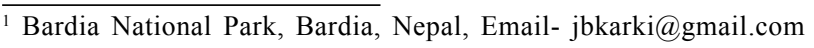


hill, Bhabar areas, and the lowland plains. A few of them have water during dry winter and in hot summer season. The major rivers have created a number of ox-bow lakes and streams where wildlife is getting water throughout the year. However, water is scarce in some parts of Churia Bhabar, lowland plains even in the Lamkauli Phanta. Because of scarcity of water wildlife move a long distance in search of water mostly in winter and in hot summer season.

In Nepal, wetland ecosystems provide considerable prime habitats for a variety of wetland flora and fauna, including 172 indigenous species of fish and over 130 species of waterfowl (Manandhar, 2062). Terai wetlands harbor endangered species of fauna such as elephant, one-horned rhino, Bengal tiger, wild buffalo (Bubalus bubalis), swamp deer, otter, gangetic dolphin, marsh crocodile, gharial and more than 18 types of uncommon and rare resident birds (Maskey, 1992).

The torrential rains have created a number of gullies and streams in foothills of Churia and in lowland plains. These gullies and streams detain rain water temporarily in the rainy seasons which support wildlife. The soil structure in the lowland plains is clay loam and brownish in color that held rain water for longer period in the lowland plains. The wild boar and other fauna use drainage sites for wallowing during rainy season. A long time use of such areas by various species shows that these areas have to be developed as small waterhole where wildlife get water during some part of the year. Before, constructing waterholes, wildlife mostly used to congregate in the flood plains where perpetual water source is available. As wildlife concentrate in limited areas, competition for shelter, water and food is obvious. Therefore, since the establishment of park, 19 waterholes were constructed with the financial support of government and the conservation partners (WWF Nepal, NTNC, WTLCP) in the lowland plain of Sal (Shorea robusta) forests and the Lamkauli Phanta. Limited studies on wildlife in the manmade waterholes have been done in the BNP. A long term study on the relationship between waterholes and the distribution and abundance of fauna in the manmade waterhole is necessary. Thus, action study on presence of fauna in the manmade waterholes was carried out in BNP from June 14 to June 22, 2009 and updated for this article.

\section{Study area}

Bardia National Park, established in 1976, lies in the mid-west Terai (Lowland) in Bardia and Banke districts of Nepal $\left(28^{\circ} 15^{\prime} \mathrm{N}-81^{\circ} 40 \mathrm{E}\right)$ and it is occupied by the largest $968 \mathrm{~km}^{2}$ wilderness area of Nepal. The altitude ranges from $152 \mathrm{~m}$ to $1441 \mathrm{~m}$ with characteristic Churia ridges, rugged foot hills, Bhabar zones, lowland plains and alluvial flood plains of the Karnali and Babai rivers. With the combination of these features, it has created a unique ecosystem and become famous for the lust valley of tall grassland in South Asia (Pokharel, 1993).

The climate is South Asian monsoonal sub-tropical type, about $85 \%$ of the rainfall occurs from June to September (GoN, 1974). The heavy pre-monsoon shower in March and April is also quite common. 
The Bardia National Park is rich in biodiversity with 10 nationally important species of mammals (tiger, rhino, Asian wild elephant, swamp deer, pygmy hog (Sus salvanius), fourhorned antelope, hidpid hare (Caprolagus hispidus), Gangetic dolphin, hyaena, wild dog); 6 species of birds (Bengal florican (Eupodotis indica) giamt horn bill (Buceros bicornis ), white throated bush chat (Saxicola insignis), bristled grass warbler (Chaetorinis striatus), black-caped kingfisher, swamp partridge (Francolinas sp.)) and 4 species of reptiles Indian python (Python molurus), gharial (Gavialis gangeticus), monitor lizard (Varanas flavescens), Indian pangoline (Manis crassicaudata). The fauna diversity in this park are 59 species of mammals, more than 400 species of bird, 121 species of fishes, and 25 species of reptiles.

\section{Objectives}

The aim of this study was to study on wildlife use of the manmade waterhole by examining signs to determine uses of the manmade water holes by fauna and, and to measure quantity of water in the manmade waterhole during hot summer season.

\section{Method}

The study of manmade waterhole was carried from July 14, 2009 to July 22, 2009. The surface area and water depth was measured. The observation of fauna was carried out using various signs such as pellets/scats, foot prints/hoof marks and feeding signs.

\section{Result}

Area (length and breath), depth of 19 manmade waterholes were measured by tape from 14-22, July 2009. Name/s, location, surface area and quantity are measured/estimated (Table 1). Nine species were recorded the Asiatic wild elephant (Elaphus maximus), Bengal tiger (Panthera tigris), one horned rhinoceros (Rhinoceros unicornis), Spotted deer (Axis axis), wild boar (Sus scrofa), samber deer (Cervus unicolor), blue bull (Boselaphus tragocamelus), four-horned antelope (Tetracerus quadricornis) and swamp deer (Cervus devauceli devauceli). The number of species signs observed in the manmade water holes is given in the table 2 .

Among 19 waterholes (Map 1), 5 dried in hot summer season (Ganesh Tal, Gaida Tal, Lamkauli Centre Tal, Tholokhola Tal and Four-horned antelope Tal) but were visited by wildlife except the Lamkauli Bearing Tal (located nearby the area of other waterholes where water is available throughout the year). The study witnessed that wildlife had still been visiting dry waterholes to search water which means they are deprived of water in these areas.

The signs of swamp deer were observed in one waterhole and four-horned antelope in two water holes, all of these waterholes were dried in hot summer seasons. The swamp deer and four-horned antelope are of national importance for conservation and live proximity to water. 
The total numbers of waterholes visited by fauna were Elephant (18), Rhino (13), Tiger (15), Swamp deer (1), Four-horned antelope (2), Blue bull (8), Samber deer (15), Spotted deer (16) and Wild boar (16) (Graph 1).

Table 1. Name, location, surface area and water depth of waterhole in BNP.

\begin{tabular}{|c|l|c|c|c|c|}
\hline SN & Name of Wetland & Latitude & Longitude & $\begin{array}{c}\text { Wetland's } \\
\left.\text { Area } \mathbf{( m}^{\mathbf{2}}\right)\end{array}$ & $\begin{array}{c}\text { Water } \\
\text { Volume } \mathbf{( m}^{\mathbf{3}} \mathbf{)}\end{array}$ \\
\hline 1 & Khodab Tal & 3156026 & 0527697 & 2695 & 2964.5 \\
\hline 2 & Dhanes Tal & 3159313 & 0528899 & 2184 & 2402.4 \\
\hline 3 & Hatti Tal & 3160000 & 0528123 & 2214 & 996.3 \\
\hline 4 & Ganesh Tal & 3161442 & 0526966 & 861 & Dry \\
\hline 5 & Barahasingha Tal & 3152520 & 0525599 & 660 & 198.0 \\
\hline 6 & Nilgai Tal & 3150999 & 0525603 & 1848 & 831.6 \\
\hline 7 & Jarayo Tal & 3154192 & 0525240 & 1419 & 851.4 \\
\hline 8 & Chandrama Tal & 3153940 & 0525866 & 1417 & 323.8 \\
\hline 9 & Devta Tal & 3157266 & 0527692 & 1102 & 771.4 \\
\hline 10 & Sarju Tal & 3156816 & 0529552 & 1748 & 1048.8 \\
\hline 11 & Lamkauli Tal & 3153120 & 0527302 & 1536 & 307.2 \\
\hline 12 & Lamkauli S. Tal & 3153680 & 0527302 & 697 & 418.2 \\
\hline 13 & Lamkauli T. Tal & 3153680 & 0527784 & 3212 & 803 \\
\hline 14 & Lamkauli C. Tal & 3153827 & 0527784 & 297 & Dry \\
\hline 15 & Lamkauli N. Tal & 3154282 & 0528122 & 572 & 57.2 \\
\hline 16 & Gaida Tal & 3150749 & 0523222 & 770 & Dry \\
\hline 17 & Jarayo Tal & 3158063 & 0532358 & 594 & 178.2 \\
\hline 18 & Chauka Tal & 3139201 & 0542543 & 966 & Dry \\
\hline 19 & Tolo Khalla Tal & 3132479 & 0548337 & 5000 & Dry \\
\hline
\end{tabular}

Table 2.The number of fauna observed in manmade waterhole in BNP.

\begin{tabular}{|c|c|c|}
\hline SN & $\begin{array}{l}\text { Name of } \\
\text { Wetland }\end{array}$ & Important wildlife species observed in the manmade waterholes \\
\hline 1 & Khodab Tal & Elephant, Tiger, Rhino, Spotted deer, Wild boar \& Samber deer \\
\hline 2 & Dhanes Tal & Elephant, Tiger, Rhino, Spotted deer, Wild boar \& Samber deer \\
\hline 3 & Hatti Tal & Elephant, Tiger, Rhino, Spotted deer, Wild boar \& Samber deer \\
\hline 4 & Ganesh Tal & Elephant, Tiger, Rhino, Spotted deer, Wild boar \& Samber deer \\
\hline 5 & Barahasingha Tal & $\begin{array}{l}\text { Elephant, Tiger, Rhino, Spotted deer, Wild boar \& Samber deer, } \\
\text { Blue bull }\end{array}$ \\
\hline 6 & Nilgai Tal & $\begin{array}{l}\text { Elephant, Tiger, Rhino, Spotted deer, Wild boar \& Samber deer, } \\
\text { Blue bull }\end{array}$ \\
\hline 7 & Jarayo Tal & $\begin{array}{l}\text { Elephant, Tiger, Rhino, Spotted deer, Wild boar \& Samber deer, } \\
\text { Blue bull }\end{array}$ \\
\hline 8 & Chandrama Tal & $\begin{array}{l}\text { Elephant, Tiger, Rhino, Spotted deer, Wild boar \& Samber deer, } \\
\text { Blue bull }\end{array}$ \\
\hline 9 & Devta Tal & $\begin{array}{l}\text { Elephant, Tiger, Rhino, Spotted deer, Wild boar \& Samber, Blue } \\
\text { bull }\end{array}$ \\
\hline
\end{tabular}




\begin{tabular}{|c|l|l|}
\hline 10 & Sarju Tal & $\begin{array}{l}\text { Elephant, Tiger, Rhino, Spotted deer, Wild boar \& Samber deer, } \\
\text { Blue bull }\end{array}$ \\
\hline 11 & Lamkauli Tal & $\begin{array}{l}\text { Elephant, Tiger, Rhino, Spotted deer, Wild boar \& Samber deer, } \\
\text { Blue bull }\end{array}$ \\
\hline 12 & Lamkauli S. Tal & $\begin{array}{l}\text { Elephant, Tiger, Rhino, Spotted deer, Wild boar \& Samber deer, } \\
\text { Blue bull }\end{array}$ \\
\hline 13 & Lamkauli T. Tal & Spotted deer, Blue bull, Elephant, wild boar \& Tiger \\
\hline 14 & Lamkauli B. Tal & wildlife sign not recorded \\
\hline 15 & Lamkauli N. Tal & Spotted deer, Blue bull, Elephant, Wild boar \& Tiger \\
\hline 16 & Gaida Tal & Rhino, Elephant \& Swamp deer \\
\hline 17 & Jarayo Tal & Tiger, Elephant, Samber deer, Spotted deer, Wild boar \\
\hline 18 & Chauka Tal & Four-horned antelope, Elephant, Tiger, Samber deer, Spotted deer \\
\hline 19 & Tolo Khalla Tal & Four-horned antelope, Elephant, Tiger, Samber deer, Spotted deer, \\
\hline
\end{tabular}

Among 5 dry waterholes (Ganesh Tal, Gaida Tal, Lamkauli Centre Tal, Tholo khola Tal and Chauka Tal), Gaida Tal was visited by Rhino and Swamp deer. These animals live in water rich areas in the lowland plains. In Chauka Tal, sings of four-horned antelope, elephant, tiger, samber deer and spotted deer were observed. Samber deer visit waterholes readily and swim with the body submerged (Prater, 1971). The small sized four-horned antelope drink regularly and they are much more dependent on water. The signs of tiger were found in 15 waterholes and among them 5 were dry. Tiger live in humid ever green forests, in the dry open jungle, in the grassy swamps of the Terai and the neighbor hood of large animals upon which it can pray and, ample shed to sleep in, and water to quench its thrust (Prater, 1971).

Fig. 1: The number of water holes visited by different wildlife in BNP.

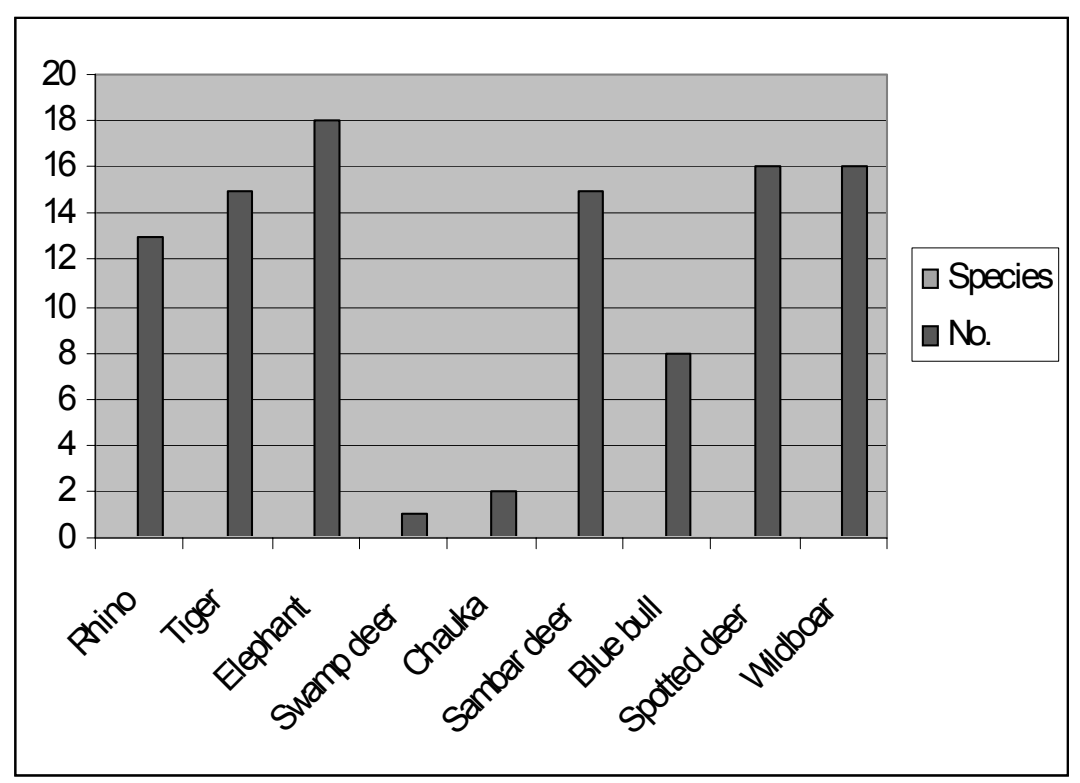




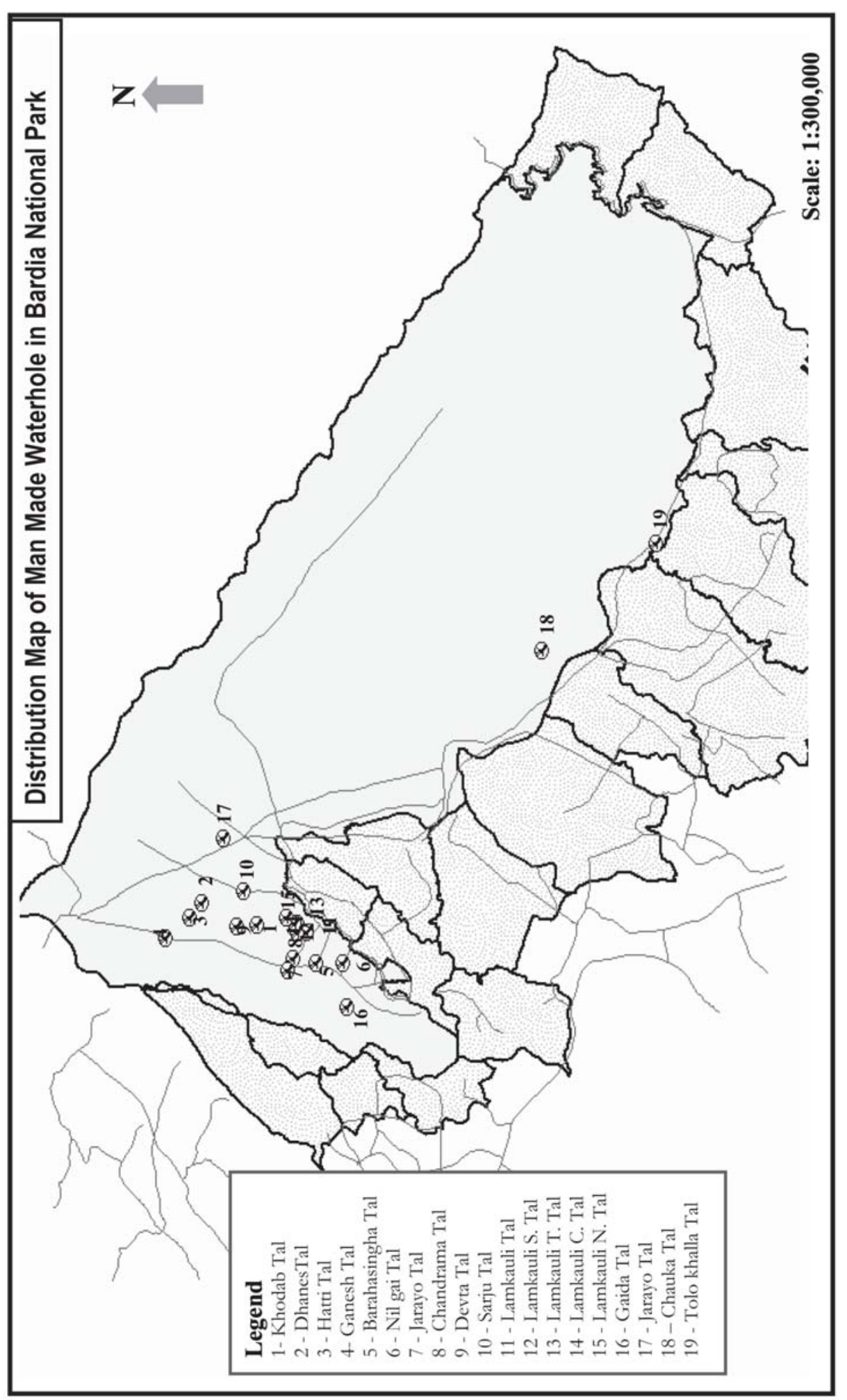




\section{Discussion}

The flood plain of Karnali and Babai rivers and their tributaries have created prominent habitats for a number of rare and endangered species which are nationally or internationally important for conservation. The number of wildlife signs - observed in 18 manmade waterholes was varied according to waterholes water retention status. A less number of species - signs were recorded in dry waterhole areas. The sign of fauna was not found in the Lamkauli Bering waterhole which was one of the dry waterholes. After construction of 19 waterholes in the lowland plains, water sources are still scarce. Among 19,5 of them were dry during study period. The signs observed - in waterholes were rhino, tiger, elephant, swamp deer, four-horned antelope, samber deer and spotted deer require much more water rather than other fauna such as samber deer, spotted deer, four-horned antelope requires less amount of water . Therefore, flood plain tall grasslands are rich of mega-herbivorous. The rhinos acquire wallow for a long or short period throughout the year depending on temperature. The tiger, swamp deer, and samber deer do swim in hot summer seasons. The elephant takes bath frequently when they feel hot.

The four-horned antelope live in undulating and hilly areas, and shelters in tall grass and open jungle. It drinks regularly and lives in near by area of water (Prater, 1971; Karki, 2002). The swamp deer found in Nepal live in the grassland proximity to forest where water resources is sufficient. The elephant, tiger and rhinos are mostly found in the flood plain areas where ox-bow lakes and waterholes are available. The Churia foot hills, Bhabar and lowland plains are considered as seasonal habitat of elephant, rhino, swamp deer and other fauna because of water scarcity and characteristic of habitats. However, waterhole management is important in areas where animals are needed to move a long distance to search water.

Prior to construction of waterhole in the Sal forests of lowland plains and Lamkauli Phanta, these areas were seasonal habitats to mage-herbivores. In hot summer seasons, when water is scarce in some parts of park, wildlife mostly congregated in the smaller areas where they fought for shelter, food and water. Poachers also took advantage of waterholes for poaching. The poaching of wildlife is one of the most concerned issues associated with their conservation. In BNP, the Babai valley, the lowland plains, and the various Phantas are considered as potential sites for poaching (Khadka, 2007). Areas very close to human settlements had higher incidents of wildlife poaching. The poachers generally use net, poison, home made nasal gun, electrocutions, dogs, pit and drive to kill wildlife (BNP official record, unpublished).

Most of the manmade waterholes lie in the Sal Forest of lowland plains and the Lamkauli Phanta, where ground vegetation is low and wildlife visibility is high. As these places are also very close to human settlement and east-west high way becomes easily accessible to poachers. Generally, waterhole sites are considered as high risk places for poaching. Aregular patrolling and monitoring system is necessary to build up to protect wildlife. Before constructing any waterhole, wildlife protection measure should be developed. Without taking initiation of 
protection measure, it is better to leave the areas as it is without any intervention. Previously constructed waterholes, which were dry in the hot summer seasons need to be improved. The protection measure of these areas should be revitalized because the nationally important fauna are found to be living in the near by areas of waterhole.

\section{Reference}

GoN,1993. Statistical Year Book of Nepal, Government of Nepal, Kathmandu, Nepal. Khadka, G.B. 2007. Status and Conservation Issues of Barasingha (Cervus duvauceli duvauceli) in Nepal. A research report submitted in the partial fulfillment of the requirement for the degree of Bachelor of Science in Forestry.

Manandhar, L.P. 2062. Wetland Management: Prospects and Constraints, Biodivesity conservation efforts in Nepal. Special issue published on the occasion of $10^{\text {th }}$ wildlife week 2062.

Maskey, T.M. 1992. Socio-economic and biophysical pressure on wetland of Nepal. In T.B. Shrestha and Bishnu Bhandari (eds.) Proceedings of the First meeting on Wetlands Management in Nepal, Kathmandu, 26 May, 1992. Kathmandu: IUCN and DNPWC.

Pokharel, S.K, 1993. Floristic Composition, Biomass production, and Biomass harvest in the grassland of the Bardia National Park, Bardia, Nepal. A thesis submitted to partial fulfillment of the requirement for the degree of master of sciences (management of natural resources and sustainable agriculture), Resources and Sustainable Agriculture), As Norway.

Prater, S.H. 1971. The book of Indian animals, Bomay Natural History Society, Oxford University Press. 